Article

\title{
Perceived Effects of Climate Change and Extreme Weather Events on Forests and Forest-Based Livelihoods in Malawi
}

\author{
Harold L. W. Chisale 1,2,*(D), Paxie W. Chirwa ${ }^{1}$, Folaranmi D. Babalola ${ }^{1,3}$ and Samuel O. M. Manda ${ }^{4,5}$ (D) \\ 1 Forest Science Postgraduate Programme, University of Pretoria, Pretoria 0028, South Africa; \\ paxie.chirwa@up.ac.za (P.W.C.); babalola.fd@unilorin.edu.ng (F.D.B.) \\ 2 Department of Forestry, Bunda Campus, Lilongwe University of Agriculture and Natural Resources, \\ Lilongwe P.O. Box 219, Malawi \\ 3 Department of Forest Resources Management, University of Ilorin, Ilorin 240003, Nigeria \\ 4 Biostatistics Research Unit, South African Medical Research Council, Pretoria 0001, South Africa; \\ samuel.manda@mrc.ac.za \\ 5 Department of Statistics, University of Pretoria, Pretoria 0028, South Africa \\ * Correspondence: u18264248@tuks.co.za or chisale.harold2@gmail.com; Tel.: +27-845178998
}

\section{check for} updates

Citation: Chisale, H.L.W.; Chirwa, P.W.; Babalola, F.D.; Manda, S.O.M. Perceived Effects of Climate Change and Extreme Weather Events on Forests and Forest-Based Livelihoods in Malawi. Sustainability 2021, 13, 11748. https://doi.org/10.3390/ su132111748

Academic Editors: Baojie He, Ayyoob Sharifi, Chi Feng and Jun Yang

Received: 2 September 2021

Accepted: 13 October 2021

Published: 25 October 2021

Publisher's Note: MDPI stays neutral with regard to jurisdictional claims in published maps and institutional affiliations.

Copyright: (c) 2021 by the authors. Licensee MDPI, Basel, Switzerland. This article is an open access article distributed under the terms and conditions of the Creative Commons Attribution (CC BY) license (https:/ / creativecommons.org/licenses/by/ $4.0 /)$.

\begin{abstract}
The emerging risks and impacts of climate change and extreme weather events on forest ecosystems present significant threats to forest-based livelihoods. Understanding climate change and its consequences on forests and the livelihoods of forest-dependent communities could support forestbased strategies for responding to climate change. Using perception-based assessment principles, we assessed the effects of climate change and extreme weather events on forests and forest-based livelihood among the forest-dependent communities around the Mchinji and Phirilongwe Forest Reserves in the Mchinji and Mangochi districts in Malawi. Content analysis was used to analyze qualitative data. The impact of erratic rainfall, high temperatures, strong winds, flooding, and droughts was investigated using logistic regression models. The respondents perceived increasing erratic rainfall, high temperatures, strong winds, flooding, and droughts as key extreme climate events in their locality. These results varied significantly between the study sites $(p<0.05)$. Erratic rainfall was perceived to pose extended effects on access to the forest in both Phirilongwe in Mangochi (43\%) and Mchinji (61\%). Climate change was found to be associated with reduced availability of firewood, thatch grasses, fruits and food, vegetables, mushrooms, and medicinal plants $(p<0.05)$. Erratic rainfall and high temperatures were more likely perceived to cause reduced availability of essential forest products, and increased flooding and strong winds were less likely attributed to any effect on forest product availability. The study concludes that climate change and extreme weather events can affect the access and availability of forest products for livelihoods. Locally based approaches such as forest products domestication are recommended to address threats to climate-sensitive forest-based livelihoods.
\end{abstract}

Keywords: forest dependent communities; essential forest products; sensitivity; binary regression model; forest-based livelihoods; climate change

\section{Introduction}

Climate change and variability are some of the most overwhelming challenges facing humanity in the 21th century, thereby threatening the attainment of sustainable development goals [1]. Although the major impacts of climate change are evenly distributed around the globe, some parts of the world are projected to experience the worst impacts due to several factors. Sub-Saharan Africa, for instance, as elsewhere in developing countries, is more vulnerable to climate change due to poverty and poor infrastructure development [1-3]. In addition, sub-Saharan Africa is more dependent on rain-fed agriculture and land-based resource use such as forests, freshwater, and riverine systems as sources of potable water, fish, and transport [4]. Specifically, the Miombo woodlands of southern 
Africa support the livelihoods of over 100 million rural and 50 million urban residents apart from sustaining the national economies of these countries [5].

The FAO [6] reports that global food production systems have greatly been affected by climate change. This problem is exacerbated by the low adaptive capacities of poor communities, which reduces their resilience [7]. As such, forest products have been used to bolster the low food production of the rural communities since time immemorial [5]. Thus, rural household livelihoods in most developing countries are highly dependent on forest resources. Oeba et al. [8] affirm that forests and tree-based systems complement agricultural production in providing better and more nutritionally balanced diets. In addition, forests provide wood fuel for cooking and a greater variety of food consumption choices such as wild food and vegetables, fruits, and fodder for livestock, particularly during lean seasons and periods of vulnerability [8-11]. To the marginalized groups such as forest communities, forests deliver a broad set of ecosystem services, which enhance and support crop production [12].

It has been estimated that approximately 20 per cent of the world population is forestdependent [13]. In Malawi, as elsewhere in developing countries, the majority of the rural household livelihoods and the large proportion of the urban households are highly dependent on forest resources to meet their nutritional, energy, cultural, and medicinal needs $[5,6,10,14]$. Forest resources are crucial for rural development in Malawi. The dominant rural livelihood activities in Malawi, as elsewhere in Africa, are farming, animal husbandry, and harvesting and trade in forest resources [15]. For example, Makungwa [16] reported that $63 \%$ of the rural population in Malawi continues to rely on traditional medicine to cure ailments. This translates into 9.5 million people being dependent on traditional medicine in Malawi. However, in addition to forest degradation and deforestation, climate change and extreme weather events present a huge challenge to forest-based livelihoods. Concerning deforestation, Ngwira and Watanabe [17] estimated that about $30,000-40,000$ hectares of forest land in Malawi is lost annually due to increased agricultural activities and excessive wood and charcoal biomass consumption.

Sein et al. [18] indicated that some of the extreme weather events that affect agriculture production include increased global temperatures and erratic rainfall (both unpredictable increase and decrease in rainfall amounts). Other studies have revealed that erratic rainfall as climate variability is the main trigger of some extreme weather events such as droughts and floods $[1,18,19]$. To support this assertion in the forestry sector, Ofoegbu et al. [11] revealed that forest-based households were very likely to perceive that drought reduces the availability of firewood in Vhembe, South Africa. In another study in Zambia, Robledo et al. [20] found that flooding positively influences mushroom reproduction and harvesting and negatively affects honey production. The study further revealed that drought, if not severe, can boost honey production due to its positive impacts on inducing flowering. However, extended droughts were revealed to kill bees, thereby negatively affecting honey production [20].

The risks and impacts of climate change and extreme weather on forest ecosystems are increasingly becoming serious threats to forest-dependent communities $[1,21,22]$. The observed and predicted impacts of climate change is projected to have an extensive range of consequences, which include droughts, floods hailstorms, and erratic rainfall, ultimately reducing crop productivity, among others $[1,11,15,23,24]$. These impacts also present significant threats to forests, livelihoods, and rural development, which may lead to increased poverty levels. In a recent assessment of the future impacts of climate change on Malawi forests, Edward et al. [15] reported that Malawi's current dry forests will be replaced by thorn woodland forests with a significant reduction in the living biomass of the forests. This presents many challenges and opportunities for individuals, households, and the wider society.

Klein [25] argued that even though climate change and variability are considered as a common occurrence, their manifestation is local. Ofoegbu et al. [11] call for the comprehensive understanding of the forest community's demographic features and their level of 
reliance on vulnerable forest resources as paramount. This understanding is envisaged to assist in construing how climate change would manifest in the forest community being considered. Malone [26] observes that climatic events and extremes produce different levels of socio-economic impact in the same community. Davison et al. [27] also argued that the variations in the climatic impacts emanating from similar climatic events do not solely depend on the location and time of the manifestation of the event but also people's level of interaction with the forest resources in their locality.

The concern of the impact of climate change, whether physical or socioeconomic in the forestry sector, has led to the urgent need to develop and implement national and regional forest-based strategies for responding to climate change [3]. Reducing vulnerability, increasing resilience, and improving adaptation to climate change is vital in various sectors, including health and forestry [22]. However, what shapes the vulnerability, resilience, and adaptability to climate change in the forestry sector is poorly understood. This is evident in how the policy documents are framed, leaving out the forest dependents' inputs at the local level. Therefore, it is important to understand how forest-dependent communities perceive and understand the impacts of climate change on the forest for their livelihood and sustenance. This will help to address their immediate needs, which will incentivize their full participation in the implementation of forest programs that address climate change and variability [28].

Studies have shown that forest-based livelihoods are insecure due to the long history of marginalization, exclusion, unclear property rights, and remoteness $[5,6,9,29]$. Taini et al. [30] assert that vulnerability assessments globally have been concentrated on dry regions, leaving forest people out. This phenomenon has not spared Malawi, where forest-dependent communities have not been adequately represented in the climate policy development process. Mostly, forest-dependent people are marginalized and considered unimportant, leading to their exclusion. For example, Velded et al. [31] reported that forest-dependent communities are ranked the lowest economically within the communities as compared to their fellow villagers who relied on agricultural and non-farming activities in the Chiradzulo district of Malawi. However, findings from the research conducted in Malawi and Zambia revealed that increasing agriculture production and productivity reduces the reliance of forest-dependent communities on forest resources for livelihoods, thereby contributing to forest conservation [32,33].

In Malawi, studies on the impact of climate change on forest ecosystems and the contribution of the forest ecosystems services to people's livelihoods are limited. However, amongst the available literature, Jumbe [34] noted that much of it dwells on the biological aspect, rendering the social aspect not much explored. In response to this gap, a proliferation of research studies emerged with much focus on the contribution of the forest ecosystems services to the livelihood of the people [9,31,35-38]. Recently, an attempt to link climate change and variability to forestry and forest-dependent communities has been made $[15,32,39,40]$. However, most of these studies fail to provide critical insights in terms of effectively analyzing the perceived vulnerability of forest-dependent communities and adaptation strategies at the household level. As a result, policy-makers are not fully aware of the vulnerability of the forest people to climate change and variability.

The impacts of climate change on the livelihoods of forest-dependent communities have been documented by various authors in Malawi [35], South Africa [11], India [21,41], Ethiopia [42], China [43], Mozambique [44], and Bhutan [45]. However, no study explicitly addresses the question of which forest products, amongst those used for livelihoods by forest-dependent communities, have been affected by which climate change and extreme weather events in space and time. We anticipate those policy makers may specifically devise deliberate climate change measures and policies targeting issues at the local level. This study was therefore designed to explore the local perceptions of the impacts of climate change and variability on forests and forest communities around the Mchinji and Phirilongwe Forest Reserves in the Mchinji and Mangochi districts, respectively. To address this objective, the paper is organized into the following main sections and themes: observed 
climate change and extreme events by the forest-dependent communities over the past 20 years, effects of the observed climate change and extreme weather events on forest access for forest-based livelihoods, and assessing the sensitivity of the priority forest products to identify the key climatic impact factors.

\section{Materials and Methods}

\subsection{Study Location}

The study was conducted at two sites in Malawi (Figure 1) involving communities around Mchinji and Phirilongwe Forest Reserves in Mchinji and Mangochi districts, respectively. Mchinji Forest Reserve is found between latitudes $13^{\circ} 51^{\prime} 26^{\prime \prime}$ East and longitude $32^{\circ} 51^{\prime} 26^{\prime \prime}$ South, whereas Phirilongwe Forest Reserve is found between the latitude of $14^{\circ} 34^{\prime} 45^{\prime \prime}$ South and the longitude of $34^{\circ} 57^{\prime} 52^{\prime \prime}$ East. In these two reserves, no government intervention or project is being implemented. According to GoM [46], Mchinji district has a total land area of $3131 \mathrm{~km}^{2}$ with a total population of 602,305 people and a population density of 192 persons per square kilometre. Mangochi district has a total land area of $6729 \mathrm{~km}^{2}$ with a total population of 1,148,611 people and a population density of 171 persons per square kilometre [46]. Mchinji forest reserve was gazetted in 1924 with a total forest area of 20,885 ha, whereas Phirilongwe forest reserve, situated on the western side of Mangochi district was gazetted in the year 1924 with a total forest area of 16,129 ha. Vegetatively, both Mchinji and Phirilongwe forest reserves and the surrounding customary forest are covered with Miombo woodland with Brachystegia as a dominant tree species. The common tree species in these reserves are Brachystegia julbernadia species such as Julbernadia paniculata (Benth) Troupin, Julbernadia globiflora (Benth), Uapaca kirkiana (Müll.Arg), Pericopsis angolensis (Baker) Meeuwen, and Pterocarpus angolensis DC. On the other hand, a major available non-timber forest product being harvested in the Phirilongwe forest reserve is the Oxytenanthera abys-sinica (A. Rich) Munro (local bamboo), which commonly grows naturally on the escarpment of the Phirilongwe Mountain.

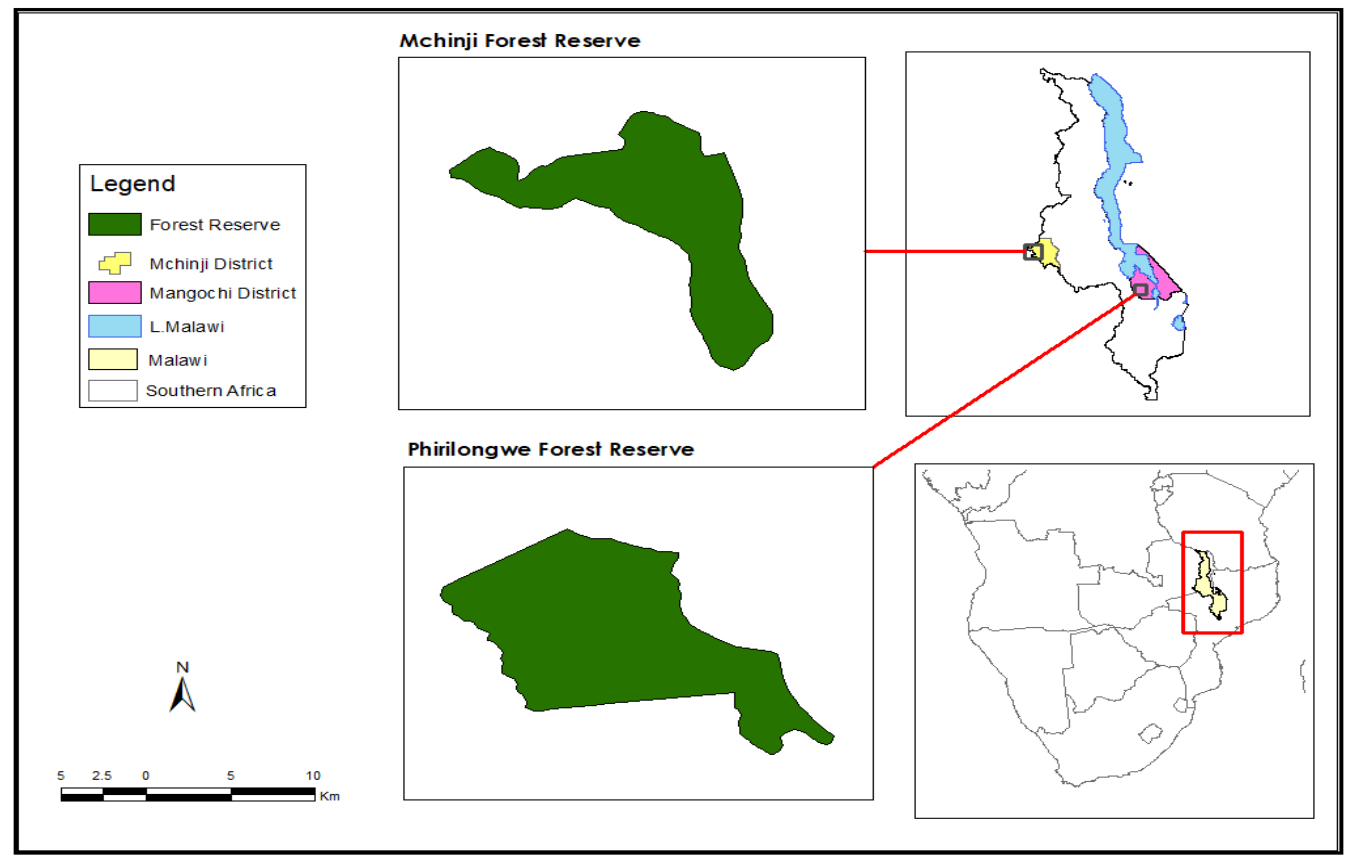

Figure 1. Map of the location of Mchinji and Phirilongwe Forest Reserves in Malawi.

\subsection{Study Design and Statistical Analysis}

We used a cross-sectional observational study design using a sample survey to collect data from select households. From each of the two districts considered in this study, one forest reserve was selected, namely, Mchinji Forest Reserve in Mchinji district and Phirilongwe Forest Reserve in Mongochi district. There were 134,799 households in Mchinji and 
152,879 households in Mangochi. The lists of households surrounding Mchinji and Phirilongwe forest reserves were accessed from their respective district councils. For sample size calculations, we used the equation in Krejcie and Morgan [47] and considered a stratified sample design where the required number of households for each forest reserve was determined independently. There is a lack of data locally on levels of reduced availability of the essential forest products. Thus, we assumed for each of the six forest-based livelihood products, they were equally likely to be reduced or not reduced, so we set the prevalence of being reduced to be $50 \%$, with a level of precision at $5 \%$ and confidence level at $95 \%$. These assumptions were for both forest reserve communities. Hence, a total of 227 and 195 households were to be sampled from Mchinji and Mangochi, respectively. The number of households to be sampled in each district were further allocated into the respective traditional authorities and subsequent villages proportionally to the size of those forest communities. For Mchiniji, 71 households were allocated to T/A Mlonyeni, 75 households to T/A Nyoka, and 81 households to T/A Mkanda. For the Mangochi district, 64 households were from T/A Mponda, 64 households from T/A Chilipa, and 67 households from $\mathrm{T} / \mathrm{A}$ Mtonda. Thus, we interviewed 422 household heads and/or their representatives in total, and the interviews were conducted between April and November 2019.

\subsection{Data Collections}

A household questionnaire was used to collect data on forest-dependent communities' perceived effects of climate change and extreme weather events on forests and forestbased livelihoods. The questions were adopted from the Climate Risk Assessment Guide Framework developed by the UNDP [48]. In the UNDP Risk Assessment Framework, the first part focuses on identifying the climate extreme events occurring in the study area. The questionnaire uses a rating technique in the assessment of the climate impact on forests. This assessment framework was also previously employed in various studies such as Lazo et al. [49], Williamson et al. [50], and Asherleaf et al. [51] in analyzing the impacts of climate change on Canadian forests. Recently, Ofoegbu et al. [11] and Basu [21] adopted the same rating techniques in assessing the impacts of climate change on the forest-based livelihood of Vhembe district and West Bengal in South Africa and India, respectively. In this paper, we only analyzed and used the data sets of the responses of participants whose ages were 35 years and above because the study had set 20 years as a recall period. Studies have shown that the probability of recalling major climate events in an area is increased by the age and experience of individuals [4,7,28,52]. Limuwa et al. [7] observed that a 20-year recalling period might be sufficient to validate the climate events of an area.

\subsection{Data Analysis}

Descriptive statistics for continuous data were expressed as means (SD) or as median and interquartile ranges for skewed distributions. Discrete or categorical data were summarized using frequencies and percentages. The independent $t$-test was used for the comparison of normally distributed data; otherwise, non-parametric alternatives were used.

The analysis of the perceived increase and decrease of each climate and the extreme event was performed to identify key priority climate hazards of the study sites. Erratic rainfall, serious floods, high temperatures, prolonged dry spells, hailstorm incidences, strong winds, and landslides were the climate variables and extreme weather events tested. In our study, we adopted the definition for climate variability by Thornton et al. [19] as the fluctuation to the natural climate system and the extreme weather events as the weather events significantly different from the usually considered normal pattern. These evaluated climate variables were compiled using the previous literature on climate extreme events in Malawi [53-56].

On the other hand, the main essential products tested were firewood, wild fruits and food, wild vegetables, bee honey, mushrooms, medicinal plants, and thatch grasses. These were the essential forest products that were revealed to contribute to forest-dependent communities' livelihoods. Each of these was taken as an outcome variable and was coded 
as 1 (reported reduced availability) and 0 (no change in the availability). Associations between discrete or categorical data were assessed using Chi-squared tests.

Associations between reduced availability (for each of the essential products) and potential predictor factors adverse climate and the extreme event (erratic rainfall, serious floods, high temperatures, prolonged dry spells, and strong winds) and sociodemographic factors (age, gender, employment, and education) were quantified by odds ratios (OR) with $95 \%$ confidence intervals (CI) from fitting multivariate logistic regression analyses. Thus, suppose $Y_{i j}$ denotes the perceived reduction in essential forest product by the respondent, say in Mchinji, where $i=1,2, \ldots, 227 ; j=1,2, \ldots, F)$ and where $\mathrm{F}$ is the number of the essential products. Furthermore, let $P_{i j}=\operatorname{Prob}\left(Y_{i j}=1\right)$ be the probability that household $i$ perceived product $j$ to be in reduced availability, then the effects of climatic and adverse events and socioeconomic factors are modelled by a logit link function as follows:

$$
\log \left(\frac{P_{i j}}{1-P_{i j}}\right)=\beta_{0}+\beta_{C}^{T} \times \text { Climate Factors }+\beta_{S E S}^{T} \times \text { SES Factors }
$$

where $\beta_{C}^{T}$ and $\beta_{S E S}^{T}$ are vectors of regression coefficients for the climatic (weather) events and socio-economic factors. We used SPSS version 25 for all the statistical analyses. Qualitative data collected through focus group discussion and key informant interviews were analyzed using content analysis.

\section{Results}

\subsection{Demographic Characteristics of the Respondents}

The results of the demographic characteristics of the respondents revealed that Mchinji was dominated by male $(53 \%)$ respondents, while Mangochi was dominated by female $(56 \%)$ respondents (Table 1). This might be attributed to the fact that most men in Mangochi are fishermen and therefore spend most of their time on the lake while their male counterparts in Mchinji are mostly farmers. Concerning age $>35$ years, Mangochi had $76.92 \%$ compared to $68.3 \%$ in Mchinji. However, we only analysed the responses of participants whose ages were 35 and above to understand their local climate trends because the study had set 20 years as a recall period. In terms of household size, $45.7 \%(n=195)$ of the households in Mangochi had a household size greater than 6 compared to 32.6\% in Mchinji. The results also indicate that $84 \%$ of respondents in Mangochi were married compared to $75 \%$ in Mchinji. In terms of education, $33 \%$ of the study population in Mchinji had accessed secondary education compared to only $10 \%$ in Mangochi. Furthermore, $24 \%$ of the respondents in Mangochi had no formal education compared to only 8\% in Mchinji.

Table 1. Demographic characteristics of the respondents.

\begin{tabular}{ccccc}
\hline & \multicolumn{2}{c}{ Proportion of Respondents in \% } & \multicolumn{2}{c}{ Chi-Square Results } \\
\hline Variable & Mchinji $(\boldsymbol{n}=\mathbf{2 2 7})$ & Mangochi $(\boldsymbol{n}=\mathbf{1 9 5})$ & $\mathbf{X}^{\mathbf{2}}$ & $\boldsymbol{p}$-Value \\
\hline Age of respondents & & & & \\
$20-34$ & 31.7 & 23.08 & 3.909 & 0.048 \\
$\geq 35$ & 68.3 & 76.92 & & \\
Gender & & & & \\
Male & 53.3 & 44.1 & 3.554 & 0.059 \\
Female & 46.7 & 55.9 & & \\
Marital status & & & & \\
Single & 4.8 & 4.1 & & \\
Married & 75.3 & 83.6 & 6.224 & 0.183 \\
Separated & 4 & 2.6 & & \\
Divorced & 7.9 & 3.1 & & \\
Widowed & 7.9 & 6.7 &
\end{tabular}


Table 1. Cont.

\begin{tabular}{ccccc}
\hline & \multicolumn{2}{c}{ Proportion of Respondents in $\%$} & \multicolumn{2}{c}{ Chi-Square Results } \\
\hline Variable & Mchinji $(\boldsymbol{n = 2 2 7 )}$ & Mangochi $(\boldsymbol{n = 1 9 5 )}$ & $\mathbf{X}^{\mathbf{2}}$ & $\boldsymbol{p}$-Value \\
\hline Level of Education & & & & \\
No formal education & 8.4 & 24.1 & 40.846 & 0.000 \\
Primary & 59 & 65.6 & & \\
Secondary & 32.6 & 10.3 & & \\
\hline Household size & & & & \\
$<3$ & 7.9 & 6.2 & & \\
3 to 5 & 59.5 & 48.2 & & \\
6 to 8 & 26.4 & 43.1 & & \\
$>9$ & 6.2 & 2.6 & & \\
\hline Employment status & & & & \\
Self-Employed & 63 & 55.38 & & \\
Unemployed & 37 & 44.62 & & \\
\hline
\end{tabular}

\subsection{Observed Climate Change and Extreme Weather Events}

The results on the observed climate variability and change show that participants from both study sites perceived a general increase in all the climate extreme events apart from hailstorms and landslides in their locality (Table 2). Erratic rainfall, which refers to the unpredictable and out of season rainfall, was perceived to have increased over the past 20 years by $83.3 \%$ and $95.4 \%$ in Mchinji and Mangochi, respectively. The chi-square test reveals that these results are statistically significant $(p=0.000)$ across the study sites.

Table 2. Perceived climate change and extreme weather events across the sites.

\begin{tabular}{|c|c|c|c|c|c|}
\hline \multirow{2}{*}{ Variable } & \multirow{2}{*}{ Response } & \multicolumn{2}{|c|}{ Proportion of Respondents (\%) } & \multicolumn{2}{|c|}{ Chi-Square Results } \\
\hline & & Mchinji $(n=155)$ & Mangochi $(n=150)$ & $X^{2}$ & $p$-Value \\
\hline \multirow{3}{*}{$\begin{array}{c}\text { Erratic } \\
\text { Rainfall }\end{array}$} & Increase & 83.3 & 95.4 & \multirow{3}{*}{17.699} & \multirow{3}{*}{0.000} \\
\hline & Decrease & 11.9 & 4.6 & & \\
\hline & Constant & 4.8 & 0 & & \\
\hline \multirow{3}{*}{$\begin{array}{l}\text { Flooding } \\
\text { events }\end{array}$} & Increase & 81.5 & 84.1 & \multirow{3}{*}{5.612} & \multirow{3}{*}{0.060} \\
\hline & Decrease & 8.8 & 11.8 & & \\
\hline & Constant & 9.7 & 4.1 & & \\
\hline \multirow{3}{*}{$\begin{array}{l}\text { High tem- } \\
\text { peratures }\end{array}$} & Increase & 71.4 & 79.5 & \multirow{3}{*}{8.020} & \multirow{3}{*}{0.018} \\
\hline & Decrease & 9.7 & 11.3 & & \\
\hline & Constant & 18.9 & 9.2 & & \\
\hline \multirow{3}{*}{$\begin{array}{l}\text { Prolonged } \\
\text { dry spells }\end{array}$} & Increase & 74.4 & 84.6 & \multirow{3}{*}{11.120} & \multirow{3}{*}{0.004} \\
\hline & Decrease & 14.1 & 4.6 & & \\
\hline & Constant & 11.5 & 10.8 & & \\
\hline \multirow{3}{*}{ Hailstorms } & Increase & 29.6 & 46.2 & \multirow{3}{*}{21.918} & \multirow{3}{*}{0.000} \\
\hline & Decrease & 60.4 & 53.8 & & \\
\hline & Constant & 10.0 & 0.0 & & \\
\hline \multirow{3}{*}{$\begin{array}{l}\text { Strong } \\
\text { Winds }\end{array}$} & Increase & 75.8 & 89.7 & \multirow{3}{*}{20.934} & \multirow{3}{*}{0.000} \\
\hline & Decrease & 8.8 & 7.7 & & \\
\hline & Constant & 15.4 & 2.6 & & \\
\hline \multirow{3}{*}{ Landslides } & Increase & 28.2 & 36.2 & \multirow{3}{*}{9.483} & \multirow{3}{*}{0.009} \\
\hline & Decrease & 51.6 & 53.8 & & \\
\hline & Constant & 20.2 & 10.0 & & \\
\hline
\end{tabular}

Though not statistically different, flooding events have increased in frequency by $81.5 \%$ in Mchinji compared to $84 \%$ in Mangochi. On the other hand, incidences of high temperatures have increased by $79.5 \%$ in Mangochi compared to $71.4 \%$ in Mchinji. The other notable perceptions on climatic events in the study are the reduction in the incidences 
of hailstorms in Mchinji (60.4\%) and Mangochi (53.8\%) and landslide incidences in Mchinji $(51.6 \%)$ and Mangochi (53.8\%). The results further revealed a significant increase in the frequency of strong winds $(p=0.000)$ and prolonged dry spells $(p=0.004)$.

\subsection{Effects of Observed Climate Change and Extreme Weather Events on Access to Forests}

The results of the analysis of the observed extreme weather events to understand how they have affected access to essential forest products for the livelihood of the forest communities in the study sites are presented in Table 3. Generally, all the observed extreme weather events were perceived to have affected and reduced access to the forest for more than three months for essential forest products for livelihoods of $65-94 \%(n=150)$ of forest-based households in Mangochi and 59-92\% in Mchinji $(n=155)$. However, it was only erratic rainfall that was perceived to pose extended reduced access to the forest for essential forest products to $61.2 \%$ and $42.5 \%$ of forest-based households in Mchinji and Mangochi, respectively. Likewise, a small proportion of forest-based households in Mchinji (32.6\%) and Phirilongwe in Mangochi (42.5\%) perceived extended reduced access to the forest due to prolonged droughts. The results further record that high temperatures did not affect access to forests for the livelihoods of $41 \%$ of forest-based households in Mchinji and $35 \%$ in Mangochi. All these results were statistically significant $(p=0.05)$ apart from the results on prolonged drought. However, the results from both the Focus Group Discussions (FDGs) and key informant interviews recorded that increased high temperatures are not a concern for the forest-dependent communities in both sites.

Table 3. Perceived effects of climate variability and change on access to forests.

\begin{tabular}{|c|c|c|c|c|c|}
\hline \multirow{2}{*}{ Climate Events } & \multirow{2}{*}{ Responses } & \multicolumn{2}{|c|}{ Proportion of Respondents in \% } & \multicolumn{2}{|c|}{ Chi-Square Results } \\
\hline & & Mchinji $(n=155)$ & Mangochi $(n=155)$ & $\mathrm{X}^{2}$ & $p$-Value \\
\hline \multirow{3}{*}{ Erratic rainfall } & \multirow{3}{*}{$\begin{array}{c}\text { not effected } \\
\text { Temporary reduced access (3-4 months) } \\
\text { Extended reduced access } \\
(>5 \text { months })\end{array}$} & 8.4 & 6 & \multirow{3}{*}{15.137} & \multirow{3}{*}{0.001} \\
\hline & & 30.4 & 51.3 & & \\
\hline & & 61.2 & 42.5 & & \\
\hline \multirow{3}{*}{ Flooding } & \multirow{3}{*}{$\begin{array}{c}\text { not effected } \\
\text { Temporary reduced access (3-4 months) } \\
\text { Extended reduced access } \\
(>5 \text { months })\end{array}$} & 26.9 & 15.9 & \multirow{3}{*}{6.014} & \multirow{3}{*}{0.048} \\
\hline & & 45.8 & 60 & & \\
\hline & & 27.3 & 24.1 & & \\
\hline \multirow{3}{*}{ High temperatures } & \multirow{3}{*}{$\begin{array}{c}\text { not effected } \\
\text { Temporary reduced access (3-4 months) } \\
\text { Extended reduced access } \\
(>5 \text { months })\end{array}$} & 41 & 35.4 & \multirow{3}{*}{9.492} & \multirow{3}{*}{0.009} \\
\hline & & 36.6 & 47.7 & & \\
\hline & & 22.4 & 16.9 & & \\
\hline \multirow{3}{*}{ Prolonged Drought } & \multirow{3}{*}{$\begin{array}{c}\text { not effected } \\
\text { Temporary reduced access (3-4 months) } \\
\text { Extended reduced access } \\
(>5 \text { months })\end{array}$} & 18.9 & 12.3 & \multirow{3}{*}{1.802} & \multirow{3}{*}{0.406} \\
\hline & & 48.5 & 51.8 & & \\
\hline & & 32.6 & 35.9 & & \\
\hline \multirow{3}{*}{ Strong winds } & \multirow{3}{*}{$\begin{array}{c}\text { not effected } \\
\text { Temporary reduced access (3-4 months) } \\
\text { Extended reduced access } \\
(>5 \text { months })\end{array}$} & 27.8 & 11.8 & \multirow{3}{*}{19.745} & \multirow{3}{*}{0.000} \\
\hline & & 48 & 69.7 & & \\
\hline & & 24.2 & 18.5 & & \\
\hline
\end{tabular}

\subsection{Sensitivity of the Priority Forest Products to Key Climatic Impact Factors}

The perceived threat of climate change and extreme weather events on essential forest products used for their livelihoods were investigated. Table $4 \mathrm{a}, \mathrm{b}$ present the results of fitting a logistics regression on whether a particular essential product was threatened or not by the effects of key observed extreme climatic events. The results show that the likelihood of perceiving a reduction in the availability of firewood was more likely due to increasing erratic rainfall ( $\mathrm{OR}=4.965, \mathrm{CI}=2.5-9.86)$. On the other hand, increased flooding incidences were less likely to be perceived to result in reduced firewood availability (OR $=0.562$, $p=0.033$ ). The likelihood of perceiving reduced availability of wild fruits and food was more likely attributed to increased dry spells $(\mathrm{OR}=1.979, \mathrm{CI}=1.136-3.449)$ and was 
less likely perceived as a result of increased flooding events ( $\mathrm{OR}=0.62, \mathrm{CI}=0.407-0.946)$. Similarly, the reduced availability of thatch grasses was more likely perceived as the adverse effects of increased erratic rains (OR $=7.584, p=0.000)$ and increased high-temperature events $(\mathrm{OR}=1.985, \mathrm{CI}=1.129-3.490)$. However, the likelihood of reduced availability of thatch grasses due to severe flooding was less likely perceived by the respondents $(\mathrm{OR}=0.33, \mathrm{CI}=0.211-0.516)$. Forest-based communities further perceived the reduced availability of mushrooms due to the adverse effects of severe erratic rainfall $(\mathrm{OR}=6.480$, $\mathrm{CI}=2.722-15.429)$. Nevertheless, the likelihood of reduced mushroom availability due to increased strong winds and flooding events were significantly less likely perceived by the communities $\mathrm{OR}=0.544, p=0.044$ and $\mathrm{OR}=0.395, p=0.000$, respectively. The likelihood of reduced availability of wild vegetables was more likely attributed to the increasingly erratic rainfall events $(\mathrm{OR}=3.154, p=0.010)$. However, communities perceived that wild vegetables were significantly less threatened by increasing flooding events $(\mathrm{OR}=0.552$, $\mathrm{CI}=0.351-0.870)$. Reduction in availability of medicinal plants was more likely perceived to be a result of adverse effects of increasing erratic rainfall $(\mathrm{OR}=5.992, p=0.000)$ and high temperatures $(\mathrm{OR}=2.436, \mathrm{CI}=1.136-4.376)$. On the other hand, increased flooding events were less likely to be perceived to cause a reduced availability of medicinal plants. The results of drought, education, and gender were not statistically significant at a $95 \%$ Confident interval. However, older respondents were less likely to report the reduced availability of fruits and food, thatch grasses, mushrooms, and vegetables. Self-employed forest residents were more likely to perceive the reduced availability of firewood, wild fruits and food, wild vegetables, and medicinal plants. Missing on the list of essential forest products is honey, where results for all predictors were statistically non-significant at a $95 \%$ Confident Interval, apart from districts in Mchinji where the reduced availability of honey was more likely perceived with $\mathrm{OR}=3.692, \mathrm{CI}=2.211-6.168$ and a $p=0.000$. In addition, the likelihood of reporting the reduced availability of wild vegetables was significantly more perceived in the Mchinji district $(\mathrm{OR}=1.684, p=0.025)$.

Table 4. (a) Odd ratios for predictor variables of reduced firewood, fruits and food, and thatch grass. (b) Odds ratios for predictor variables of reduced mushrooms, wild vegetables, and medicinal plants.

(a)

\begin{tabular}{|c|c|c|c|}
\hline & Firewood & Wild Fruits and Food & Thatch Grass \\
\hline Independent Predictor & $\begin{array}{l}\text { Odds Ratio } \\
\text { (95\% CI) }\end{array}$ & $\begin{array}{l}\text { Odds Ratio } \\
\text { (95\% CI) }\end{array}$ & $\begin{array}{l}\text { Odds Ratio } \\
\text { (95\% CI) }\end{array}$ \\
\hline Age ( $\geq 35$ years vs. $<35$ year $)$ & $0.623(0.352-1.104) *$ & $0.606(0.381-0.963)$ & $0.46(0.286-0.755)$ \\
\hline Gender (Male vs. Female) & $0.986(0.604-1.611) *$ & $1.442(0.950-2.186) *$ & $1.095(0.703-1.704)$ * \\
\hline Uneducated (Yes vs. No) & $1.572(0.745-3.313)$ * & $0.907(0.508-1.620) *$ & $1.053(0.572-1.94)$ * \\
\hline Employment (Yes vs. No) & $1.659(1.056-2.601)$ & $1.796(1.178-2.739)$ & $1.054(0.77-1.641)$ * \\
\hline District (Mchinji vs. Mangochi) & $0.63(0.376-1.053)^{*}$ & $0.758(0.496-1.160) *$ & $1.108(0.711-1.727)$ * \\
\hline Erratic rainfall (Yes vs. No) & $4.965(2.215-16.205)$ & $2.268(1.141-4.51)$ & $7.89(2.892-21.328)$ \\
\hline Flooding (Yes vs. No) & $0.434(0.277-0.678)$ & $0.62(0.407-0.946)$ & $0.33(0.211-0.516)$ \\
\hline High Temperatures (Yes vs. No) & $2.436(1.356-4.376)$ & $0.695(0.415-1.166) *$ & $1.985(1.129-3.49)$ \\
\hline Strong winds (Yes vs. No) & $1.752(0.929-3.302)^{*}$ & $0.687(0.390-1.208) *$ & $1.599(0.863-2.963)$ * \\
\hline Drought (Yes vs. No) & $0.748(0.379-1.476) *$ & $1.736(0.982-3.070) *$ & $0.602(0.329-1.101)$ * \\
\hline
\end{tabular}


Table 4. Cont.

\begin{tabular}{|c|c|c|c|}
\hline \multicolumn{4}{|c|}{ (b) } \\
\hline & Mushroom & Wild Vegetable & Medicinal Plant \\
\hline Independent Predictor & $\begin{array}{l}\text { Odds Ratio } \\
\text { (95\% CI) }\end{array}$ & $\begin{array}{l}\text { Odds Ratio } \\
\text { (95\% CI) }\end{array}$ & $\begin{array}{c}\text { Odds Ratio } \\
\text { (95\% CI) }\end{array}$ \\
\hline Age ( $\geq 35$ years vs. $<35$ year) & $0.51(0.319-0,826)$ & $0.547(0.335-0.891)$ & $0.746(0.459-1.213)$ * \\
\hline Gender (Mala vs. Female) & $0.966(0.628-1.487) *$ & $0.739(0.469-1.165) *$ & $0.93(0.596-1.452) *$ \\
\hline Uneducated (Yes vs. No) & $1.147(0.631-2.087) *$ & $0.616(0.315-1.205)$ * & $0.677(0.36-1.274) *$ \\
\hline Employ (Yes vs. No) & $1.132(0.732-1.751)$ * & $2.44(1.521-3.915)$ & $1.659(1.059-2.601)$ \\
\hline District (Mchinji vs. Mangochi) & $0.962(0.622-1,487) *$ & $1.684(1.067-2.657)$ & $1.093(0.703-1.701)$ * \\
\hline Erratic rainfall(Yes vs. No) & $6.48(2.72-15.43)$ & $3.15(1.31-7.594)$ & $5.99(2.215-16.206)$ \\
\hline Flooding(Yes vs. No) & $0.395(0.256-0.61)$ & $0.552(0.351-0.87)$ & $0.434(0.277-0.678)$ \\
\hline High temperatures(Yes vs. No) & $1.642(0.955-2.823)$ * & $1.641(0.917-2.936)$ * & $2.436(1.356-4.376)$ \\
\hline Strong winds (Yes vs. No) & $0.544(0.301-0.984)$ & $1.62(0.836-3.136) *$ & $0.916(0.494-1.698)$ * \\
\hline Drought (Yes vs. No) & $0.777(0.433-1.394) *$ & $1.616(0.837-3.120) *$ & $1.744(0.922-3.299)$ * \\
\hline
\end{tabular}

${ }^{*}$ not significant at $95 \%$ CI.

\section{Discussion}

This study set out to use perception-based assessment principles to assess the impact of climate change and extreme weather events on forests and forest-based livelihoods, adjusting for the influence of socioeconomic factors in Malawi. Two forest-dependent communities in two purposively chosen districts in Malawi were used. The section discusses the observed climate change and extreme events over the past 20 years, the effects of these observed climate change and extreme weather events on forest access for forest-based livelihoods, and the sensitivity of the priority forest products to identify the key climatic impact factors. For each of the six main essential products (firewood, wild fruits and food, wild vegetables, mushrooms, medicinal plants, and thatch grasses), a logistic regression model was used to identify its independent predictors.

\subsection{Observed Climate Variability and Extreme Events}

The study has found that the majority of the forest-dependent communities across the two study sites have perceived an increase in the assessed frequencies of various climatic factors and extreme weather events such as erratic rainfall, flooding events, strong winds, droughts, and high temperatures. These findings are in line with the results of the study by Fujisawa et al. [56], Edward et al. [15], Limuwa et al. [7], Munthali et al. [28], and Chisale [23]. Forest-based households have proven to know their local climate system in our study. This is a positive revelation as far as climate intervention adaptation is concerned. Studies have shown that perceiving local climatic changes is the first stage of the adaptation process to reduce the impacts of the perceived changing climate [21,57-59]. On the other hand, this study shows that forest-dependent communities failed to perceive the increase in the frequencies of hailstorms and landslides events of the past years. Although these might be construed as contradictory results to the findings of Msilimba and Holmes [60] and Omran et al. [61], this might be attributed to their interaction and their long term exposure to the extreme events and local climate and environment. This supports the proposition that, although climate change can be considered at regional and national level, its manifestation is always locally felt, thereby calling for in-depth empirical studies at a local level [21]. However, findings on reduced hailstorms and landslides events in Mchinji and Mangochi best explain and support the findings of Msilimba [62], which attributed hailstorms as the cause of landslides. Thus, reduced hailstorms result in reduced landslides. Furthermore, Msilimba [62] argued that landslides are frequently occurring in mountainous terrains and result in minimal socioeconomic impacts on the society and are thus not well noticed by the locals. This might also apply to the hailstorm that their impacts have not been well noticed by the forest-dependent communities in the studied sites. 


\subsection{Effects of Observed Climate Change and Extreme Events on Access to Forests}

Our study has further revealed disparities in the perceptions of the effects of climate change on access to various forest products used for livelihood. Although these findings may expose the failure on the abilities of forest-based communities to correctly identify the impacts of climate change on their livelihood [11], it gives a true insight of what these communities consider as attributes of concern from climate change impacts for their livelihood in the study sites. Arndt et al. [63] argue that local people have experience and knowledge of local climatic patterns accumulated over the years, which might not be noticed by scientific research. It may be imperative to start harnessing the use of this accumulated knowledge and experience in real-time before they become obsolete. Local communities in this study generally perceived that all the observed extreme climate events affected their access to forest products for their livelihood for over three months. It was revealed during the focus group discussion that mushrooms and medicinal herbs have been heavily affected. In addition, honey production has dwindled due to the drying of rivers. On the other hand, erratic rainfall was perceived to have an extended impact, whereas temperature has not affected their access to forest products. The results of high temperature posing no risk on forest-based livelihood in our study corroborate the findings of Ofoegbu et al. [11] and contradict the empirical findings elsewhere [64,65]. These results suggest that increased temperatures are not of concern to the local communities in Malawi and parts of Southern Africa. Furthermore, local people will always be concerned with those climate attributes that directly affect their livelihoods [21]. However, it could also be attributed to the underestimation of the climate change impacts by the local communities, as proposed by [11], which increases their vulnerability levels to the non-perceived climate trends.

\subsection{Essential Forest Products Sensitivity and Vulnerability to Climate Variability}

The study has further shown that the forest-dependent communities perceived the sensitivity of some of their forest-based livelihoods to some specific climatic events. For example, respondents perceived that the reduced availability of most essential forest products such as firewood, forest fruits and vegetables, thatch grasses, and mushrooms were more likely due to the adverse effects of increased erratic rainfall and high temperatures. Nevertheless, increased flooding and strong winds were less likely perceived to cause reduced availability of essential forest products. This suggests that not all climatic events pose the same threats to forest-based livelihood. These results support the findings of the study by Ofoegbu et al. [11] and Basu [21] in Vhembe, South Africa and Bengal in India, respectively. In this context, the study also suggests that there are different ways through which climate change affects essential forest products for livelihoods, which are perceived differently by forest-based households. Particularly, high temperatures and erratic rainfall were the only climatic events that were perceived to pose significant threats to firewood. Generally, the rest of the essential forest products significantly perceived to be threatened are all non-wood forest products, such as wild fruits and vegetables as threatened by erratic rainfall and high temperatures. Unlike the findings of Ofoegbu et al. [11], where flooding and erratic rainfall were perceived to pose no significant threat to any forest products, our study unveiled that bee honey is perceived to be threatened by flooding, and thatch grass is threatened significantly by erratic rainfall. We may speculate that their findings in Vhembe were largely influenced by the prevailing climatic conditions of the area, which is conspicuously drier as compared to the Mchinji and Mangochi districts in our study. These results may support the findings of Chilongo [9] which indicated that most high-valued wood products of the forests, such as timber, with high potential to bail them out of poverty, are beyond the reach of the local forest-dependent households in Malawi. This might be the reason for the non-perception of the timber and the construction wood products' sensitivity to climate change and variability in our study.

Generally, the findings of the sensitivity of the various essential forest products to specific climatic events provide insights on the opportunity to develop strategies and interventions to manage the forests by taking into consideration the prevailing climatic 
events. As suggested by other scholars, these results support the proposition that the perception of the impacts of climate variability and extreme events on forest-based livelihoods and natural resources are more influenced by other socioeconomic factors $[11,21,32,56,60]$. Thus, forest-dependent communities are more likely to perceive the sensitivity of those forest products that contribute more to their social welfare. Specifically, it is the heightened interaction of the climate and the social-economic pressure that affects forest use and management. This suggests that the resilience of the forest-based livelihood cannot be considered in isolation from the socio-economic needs of the forest-dependent communities. There is a need to look at it holistically, employing the systems thinking model to completely address the sustainability of the forest-based livelihood.

\section{Conclusions}

We assessed the perceived effects of climate change and extreme weather events on forests and forest-based livelihoods of the forest-dependent communities around the Mchinji and Phirilongwe Forest Reserves in Malawi. The forest-dependent communities identified increasing incidences of erratic rainfall, flooding, high temperatures, prolonged dry spells, and strong winds as key climate variability and extreme events of the study sites. Generally, all five observed extreme climate events reduced the access of the forest to forest-dependent communities for varying periods. However, only erratic rainfall was perceived to pose an extended reduction in access to the forest for livelihood. Mixed results were revealed regarding the sensitivity of essential forest products to increased extreme climate events. Respondents perceived that the reduced availability of most essential forest products was more likely due to adverse effects of increasingly erratic rainfall and high temperatures. Nevertheless, increased flooding and strong winds were less likely perceived to cause the reduced availability of essential forest products. The study has shown that climate change and extreme weather events can affect the access and availability of forest products for livelihoods. We, therefore, recommend concerted efforts and systems approaches to addressing the sensitivity of identified forest-based livelihoods to climate change and socioeconomic pressures. We further call for site-based adaptation and mitigation measures targeting the identified vulnerable forest products such as forest product domestication and respective climate threats in these study sites. We recommend further studies to understand forest use as a climate change coping strategy and assessing the adaptive capacity of these forest-based households.

Author Contributions: Conceptualization, H.L.W.C. and P.W.C.; methodology, H.L.W.C. and S.O.M.M.; software, H.L.W.C.; validation, H.L.W.C., P.W.C., F.D.B. and S.O.M.M.; formal analysis, H.L.W.C.; investigation, H.L.W.C.; resources, H.L.W.C. and P.W.C.; data curation, H.L.W.C., P.W.C.; writing—original draft preparation, H.L.W.C.; writing—review and editing, H.L.W.C., P.W.C., F.D.B. and S.O.M.M.; visualization, H.L.W.C., P.W.C., F.D.B. and S.O.M.M.; supervision, P.W.C. and F.D.B.; project administration, H.L.W.C.; funding acquisition, H.L.W.C. and P.W.C. All authors have read and agreed to the published version of the manuscript.

Funding: This research was funded collaboratively by the Lilongwe University of Agriculture and Natural Resources (LUANAR) and the University of Pretoria under the Gradate Teaching Assistantship Programme of the RUFORUM and The APC was funded by LUANAR. Samuel Manda's time on this paper was supported by the South Africa Medical Research Council.

Institutional Review Board Statement: The study was conducted according to the guidelines of the Declaration of the University of Pretoria and approved by the Faculty of Natural and Agricultural Sciences Ethics Committee (protocol code: 180000128 and date of approval; 21 January 2019).

Informed Consent Statement: Informed consent was obtained from all subjects involved in the study.

Data Availability Statement: Data not publicly available.

Acknowledgments: This project was funded by the Regional Universities Forum for Capacity Building in Agriculture (RUFORUM) under the Graduate Teaching Assistantship (GTA). Precisely, the project was funded by the University of Pretoria and the Lilongwe University of Agriculture and 
Natural Resources (LUANAR)—RUFORAM Bursary scheme. The RUFORUM Coordination office staff and the University of Pretoria Ruforum Coordinator, Frans Swanepoel, are hereby acknowledged. The forest-based households and the technical district staff both in Mchinji and Mangochi are hereby acknowledged for responding to the questionnaires. Thumbs up to all the research assistants who took part in the data collection of this project. Special mention to Solomon J. Sibale for study site map production and the study site shapefiles.

Conflicts of Interest: The authors declare no conflict of interest.

\section{References}

1. IPCC. Climate change 2014: Climate impacts, adaptation and vulnerability. In Working Group II to Intergovernmental Panel on Climate Change Fifth Assessment Report; Intergovernmental Panel on Climate Change: Geneva, Switzerland, 2014.

2. Kurukulasuriya, P.; Mendelson, R. Crop selection: Adaptation to Climate change in Africa. In Environment and Technology Production Division; International Food Policy Research Institute (IFPRI): Washington, DC, USA, 2006.

3. Chidumayo, E.; Okali, D.; Kowero, G.; Larwanou, M. (Eds.) Climate Change and African Forest and Wildlife Resources; African Forest Forum: Nairobi, Kenya, 2011.

4. IPCC. Climate change 2007: Climate impacts, adaptation and vulnerability. In Working Group II to Intergovernmental Panel on Climate Change Fourth Assessment Report; Intergovernmental Panel on Climate Change: Geneva, Switzerland, 2007; Available online: https://www.ipcc.ch/pdf/assessmentreport/ar4/wg2/ar4_wg2_full_report.pdf (accessed on 26 July 2018).

5. Ribeiro, N.S.; Grundy, I.M.; Goncalves, F.M.P.; Moura, I.; Santos, M.J.; Kamoto, J.; Barros, A.I.R.; Gandiwa, E. People in Miombo Woodlands: Socio-ecological dynamics. In Miombo Woodlands in a Changing Environment: Securing the Resilience and Sustainability of People and Woodlands; Ribeiro, N.S., Katerere, Y., Chirwa, P.W., Grundy, I.M., Eds.; Springer: Cham, Switzerland, 2020. [CrossRef]

6. FAO. State of the World's Forests 2015; FAO: Rome, Italy, 2015.

7. Limuwa, M.M.; Sitaula, B.K.; Njaya, F.; Storebakken, T. Evaluation of small-scale fishers' perceptions on climate change and their coping strategies: Insights from Lake Malawi. Climate 2018, 6, 34. [CrossRef]

8. Oeba, V.O.; Otor, S.C.; Kung'u, J.B.; Muchiri, M.N. Modelling determinants of tree planting and retention on farm for improvement of forest cover in central Kenya. Int. Sch. Res. Not. 2012, 2012, 867249. [CrossRef]

9. Chilongo, T.M.S. Forests and Livelihoods in Malawi: Looking Beyond Aggregate Income Shares. Unpublished Doctoral Disertion, School of Economics and Business, Norwegian University of Life Sciences, Ås, Norway, 2005.

10. Chirwa, P.W.; Syampungani, S.; Geldenhuys, C.J. The ecology and management of the miombo woodlands for sustainable livelihoods in southern Africa: The case for non-timber forest products. South. For. 2008, 70, 237-245. [CrossRef]

11. Ofoegbu, C.; Chirwa, P.W.; Babalola, F.D.; Francis, J. Perception-based analysis of climate change effect on forest-based livelihood: The case of Vhembe District in South Africa. Jàmbá J. Disaster Risk Stud. 2016, 8, 1-11. [CrossRef]

12. FAO. State of the World's Forests 2011; FAO: Rome, Italy, 2011.

13. FAO. State of the World's Forests 2014; FAO: Rome, Italy, 2014.

14. Senganimalunje, T.C.; Chirwa, P.W.; Babalola, F.D. Exploring the Role of Forests as Natural Assets in Rural Livelihoods and Coping Strategies Against Risks and Shocks in Dedza east, Malawi. J. Sustain. For. 2020. [CrossRef]

15. Edward, M.; Henry, U.; Maggie, M.; William, M. Modelling of climate conditions in forest vegetation zones in Malawi. World J. Adv. Res. Rev. 2019, 1, 36-44.

16. Makungwa, S. Enhancing Productivity and Estimation of Carbon in CDM Forestry Projects: A Malawi Case Study; The University of Edinburg: Edinburgh, UK, 2015.

17. Ngwira, S.; Watanabe, T. An analysis of the causes of deforestation in Malawi: A case of Mwazisi. Land 2019, 8, 48. [CrossRef]

18. Sein, M.; Nomura, H.; Takahashi, Y.; Ogata, K.; Mitsuyasu, Y. Impact of erratic rainfall from climate change on pulse production efficiency in lower Myanmar. Sustainability 2018, 10, 1-16.

19. Thornton, P.K.; Ericksen, P.J.; Herrero, M.; Challinor, A.J. Climate variability and vulnerability to climate change: A review. Glob. Chang. Biol. 2014, 20, 3313-3328. [CrossRef]

20. Robledo, C.; Clot, N.; Hammill, A.; Riché, B. The role of forest ecosystems in communitybased coping strategies to climate hazards: Three examples from rural areas in Africa. J. For. Policy Econ. 2012, 24, 20-28. [CrossRef]

21. Basu, J.P. Climate Change Adaptation and Forest Dependent Communities: An Analytical Perspective of Different Agro-Climatic Regions of West Bengal, India; Springer: New York, NY, USA, 2017.

22. Nunes, A.R. Assets for health: Linking vulnerability, resilience and adaptation to climate change. Tyndall Cent. Clim. Chang. Res. Work. Pap. 2016, 163, 1-41.

23. Chisale, H. Climate Change in Malawi and Its Implication on Natural Resource Base; LAP Lambert Academic Publishing: Sunnyvale, CA, USA, 2013; ISBN-13: 978-3659471360.

24. Pangapanga, P.I.; Jumbe, C.B.; Kanyanda, S.; Thangalimodzi, L. Unravelling strategic choices towards droughts and floods' adaptation in southern Malawi. Disaster Risk Reduct. 2012, 2, 57-66. [CrossRef]

25. Klein, R.J. Approaches, methods and tools for climate change impact, vulnerability and adaptation assessment. In Keynote Lecture to the In-Session Workshop on Impacts of, and Vulnerability and Adaptation to, Climate Change, Proceedings of the Twenty-First Session of the UNFCCC Subsidiary Body for Scientific and Technical Advice, Buenos Aires, Argentina, 6-14 December 2004; UNFCCC: Bonn, Germany, 2004; Volume 8. 
26. Malone, E.L. Vulnerability and resilience in the face of climate change: Current research and needs for population information. Popul. Action Int. 2009, 31, 16063171.

27. Davidson, D.J.; Williamson, T.; Parkins, J.R. Understanding climate change risk and vulnerability in northern forest-based communities. Can. J. For. Res. 2004, 33, 2252-2261. [CrossRef]

28. Munthali, C.K.; Kasulo, V.; Matamula, S. Smallholder farmer's perception on climate change in Rumphi District, Malawi. J. Agric. Ext. Rural Dev. 2016, 8, 202-210.

29. Locatelli, B.; Kanninen, M.; Brockhaus, M.; Colfer, C.P.; Murdiyarso, D.; Santoso, H. Facing an Uncertain Future: How Forests and People Can Adapt to Climate Change; Forest Perspectives no. 5; CIFOR: Bogor, Indonesia, 2008.

30. Tiani, A.M.; Besa, M.C.; Devisscher, T.; Pavageau, C.; Butterfield, R.; Bharwani, S.; Bele, M.Y. Assessing Current Social Vulnerability to Climate Change: A Participatory Methodology; Working Paper 169; CIFOR: Bogor, Indonesia, 2015.

31. Vedeld, P.; Angelsen, A.; Bojö, J.; Sjaastad, E.; Berg, G.K. Forest environmental incomes and the rural poor. For. Policy Econ. 2007, 9, 869-879. [CrossRef]

32. Fisher, M.; Chaudhury, M.; McCusker, B. Do forests help rural households adapt to climate variability? Evidence from Southern Malawi. World Dev. 2010, 38, 1241-1250. [CrossRef]

33. Bwalya, S.M. Household dependence on forest income in rural Zambia. Zamb. Soc. Sci. J. 2011, 2, 6.

34. Jumbe, C.B.L. Community Forest Management, Poverty and Energy Use in Malawi. Ph.D. Thesis, Department of Economics and Resource Management, Norwegian University of Life Sciences, Ås, Norway, 2005.

35. Fisher, M. Household welfare and forest dependence in Southern Malawi. Environ. Dev. Econ. 2004, 9, 135-154. [CrossRef]

36. Fisher, M.; Shively, G.E. Agricultural subsidies and forest pressure in Malawi's Miombo Woodlands. J. Agric. Resour. Econ. 2007, 349-362.

37. Bandyopadhyay, S.; Shyamsundar, P.; Baccini, A. Forests, biomass use and poverty in Malawi. Ecol. Econ. 2011, 70, $2461-2471$. [CrossRef]

38. Senganimalunje, T.C.; Chirwa, P.W.; Babalola, F.D.; Graham, M.A. Does participatory forest management program lead to efficient forest resource use and improved rural livelihoods? Experiences from Mua-Livulezi Forest Reserve, Malawi. Agrofor. Syst. 2016, 90, 691-710. [CrossRef]

39. USAID. Malawi Climate Change Vulnerability Assessment 2013: Africa and Latin America Resilience to Climate Change Project (ARCC) Report; USAID-Malawi: Washington, DC, USA, 2013.

40. GoM. The Malawi Vulnerability Assessment Committee (MVAC); Bulletin No. 8; GoM: Lilongwe, Malawi, 2012 ; Volume 2.

41. Sharma, R.C. Forest for Poverty Alleviation: Chhattisgarh Experience; Food and Agriculture Organisation: Rome, Italy, 2005; Volume 109.

42. Mamo, G.; Sjaastad, E.; Vedeld, P. Economic dependence on forest resources: A case from Dendi District, Ethiopia. For. Policy Econ. 2007, 9, 916-927. [CrossRef]

43. Shougong, Z.; Weichang, L.; Wenming, L.; Huafeng, D. Community forestry in mountain development: A case study in Guizhou Province, China. In Forests for Poverty Reduction: Changing Role for Research, Development and Training Institutions; Sim, H.C., Appanah, S., Hooda, N., Eds.; FAO: Bangkok, Thailand, 2003.

44. Lynam, T.; Cunliffe, R.; Mapaure, I. Assessing the importance of woodland landscape locations for both local communities and conservation in Gorongosa and Muanza Districts, Sofala Province, Mozambique. Ecol. Soc. 2004, 9. [CrossRef]

45. Tshering, D. 23 Forests for Poverty Alleviation-Case of Bhutan; Food and Agriculture Organisation: Rome, Italy, 2005; Volume 157.

46. GoM. Population and Housing Census, 2018; National Statistical Office: Zomba, Malawi, 2018.

47. Krejcie, R.V.; Morgan, D.W. Determining sample size for research activities. Educ. Psychol. Meas. 1970, 30, 607-610. [CrossRef]

48. United Nations Development Programme (UNDP). Climate Risk Assessment Guide-Central Asia, Project: Enabling Integrated Climate Risk Assessment for CCD Planning in Central Asia; CAMP Alatoo Public Foundation: Almaty, Kazakhstan, 2013.

49. Lazo, J.K.; Kennell, J.C.; Fisher, A. Expert and Layperson perceptions of ecosystem risk. Risk Anal. 2000, 2, 179-193. [CrossRef]

50. Williamson, T.B.; Parkins, J.R.; McFarlane, B.L. Perceptions of climate change risk to forest ecosystems and forest-based communities. For. Chron. 2005, 81, 710-716. [CrossRef]

51. Asherleaf. Climate Risk E Opportunity Management; Asher Innovation: Mont-Liban, Lebanon, 2012; pp. 1-12.

52. Mittal, N.; Pope, E.; Whitfield, S.; Bacon, J.; Bruno Soares, M.; Dougill, A.J.; Homberg, M.V.D.; Walker, D.P.; Vanya, C.L.; Tibu, A.; et al. Co-designing indices for tailored seasonal climate forecasts in Malawi. Front. Clim. 2021, 2, 30. [CrossRef]

53. Haghtalab, N.; Moore, N.; Ngongondo, C. Spatio-temporal analysis of rainfall variability and seasonality in Malawi. Reg. Environ. Chang. 2019, 19, 2041-2054. [CrossRef]

54. Vincent, K.; Dougill, A.J.; Dixon, J.L.; Stringer, L.C.; Cull, T. Identifying climate services needs for national planning: Insights from Malawi. Clim. Policy 2017, 17, 189-202. [CrossRef]

55. Pauw, K.; Thurlow, J.; Van Seventer, D.E. The economic costs of extreme weather events: A hydrometeorological CGE analysis for Malawi. Environ. Dev. Econ. 2011, 16, 177-198. [CrossRef]

56. Fujisawa, M.; Gordes, A.; Heureux, A. Assessing the impacts of climate change on the agriculture sectors in Malawi. In The MOSAICC Methodology for National Adaptation Planning; FAO: Rome, Italy, 2020. [CrossRef]

57. Füssel, H.M.; Klein, R.J.T. Climate change vulnerability assessments: An evolution of conceptual thinking. Clim. Chang. 2006, 75, 301-329. [CrossRef] 
58. Ishaya, S.; Abaje, I.B. Indigenous people's perception on climate change and adaptation strategies in Jema'a local government area of Kaduna State, Nigeria. J. Geogr. Reg. Plan. 2008, 1, 138-143.

59. Mertz, O.; Mbow, C.; Reenberg, A.; Diouf, A. Farmers' perceptions of climate change and agricultural adaptation strategies in rural Sahel. Environ. Manag. 2009, 43, 804-816. [CrossRef]

60. Msilimba, G.; Holmes, P. A landslide hazard assessment and vulnerability appraisal procedure; Vunguvungu/Banga catchment, Northern Malawi. Nat. Hazards 2005, 24, 99-216. [CrossRef]

61. Omran, A.; Schwarz-Herion, O. The Impact of Climate Change on Our Life: The Questions of Sustainability; Springer: New York, NY, USA, 2018.

62. Msilimba, G.G. The socioeconomic and environmental effects of the 2003 landslides in the Rumphi and Ntcheu Districts (Malawi). Nat. Hazards 2010, 53, 347-360. [CrossRef]

63. Arndt, C.; Schlosser, A.; Strzepek, K.; Thurlow, J. Climate change and economic growth prospects for Malawi: An uncertainty approach. J. Afr. Econ. 2014, 23 (Suppl. 2), ii83-ii107. [CrossRef]

64. Naidoo, S.; Davis, C.; Van Garderen, E.A. Forests, Rangelands and Climate Change in Southern Africa; Food and Agriculture Organization: Rome, Italy, 2013; Volume 12.

65. Gauthier, S.; Bernier, P.; Burton, P.J.; Edwards, J.; Isaac, K.; Isabel, N.; Jayen, K.; Le Goff, H.; Nelson, E.A. Climate change vulnerability and adaptation in the managed Canadian boreal Forest. Environ. Rev. 2014, 22, 256-285. [CrossRef] 